\title{
Clinical trials end at gene-therapy institute...
}

\section{Paul Smaglik, Washington}

Reflecting suggestions that it may have been over-zealous in promoting the human applications of gene-therapy research, the University of Pennsylvania announced last week that its Institute for Human Gene Therapy (IHGT), which was designed to embrace a 'bench-to-bedside' approach, will no longer conduct clinical trials.

The decision follows investigations into the death of an 18-year-old man, Jesse Gelsinger, in one such trial at the institute last autumn (see Nature 401, 517-518; 1999). Gelsinger's death and the ensuing fallout have already put the field under greater scrutiny, and could lead to regulations that would make conducting any clinical trial more difficult and more expensive.

Part of the fallout has been the suspension by the US Food and Drug Administration (FDA) of all five of the IHGT's trials, amid revelations that many other US gene-therapy investigators failed to report adverse events to the US National Institutes of Health.

Last week, the Department of Health and Human Services (DHHS) called for better training of clinical investigators, stricter guidelines on obtaining informed consent for experiments, and more aggressive monitoring of clinical trials. These recommendations reflect criticisms made by the FDA when it suspended the IHGT's clinical trials (see Nature 403, 354; 2000).

Senator William Frist (Republican, Tennessee), chair of the Senate's Subcommittee on Health, Education, Labor and Pensions, noted during a subcommittee hearing last week that these recommendations resemble those made in 1998, which a recent progress report says the department has largely failed to meet.

Frist added that the new DHHS guidelines ignore many other recommendations made by the department's Office of Inspector General, particularly on improving the review boards that monitor clinical trials for research institutions.

The DHHS has already said that it intends to introduce laws under which investigators could be fined up to $\$ 250,000$, and institutions up to $\$ 1$ million, for failing to meet the stricter standards. But Frist suggested that instead further laws may be needed to make researchers follow more stringent reporting and monitoring requirements.

An external report commissioned by the university on Gelsinger's death, and published last week, concluded that tougher requirements would be costly. "Since the university will be judged by the same standards as industry, it will now be necessary to invest considerably more resources for compliance than has historically been necessary for independent university-initiated research," it says.

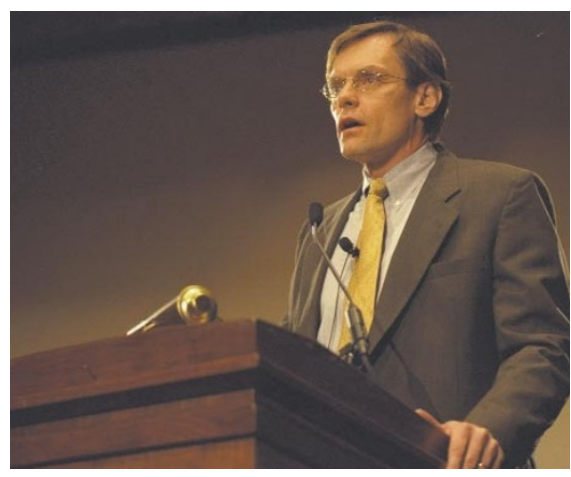

Wilson: will remain at the institute, but observers believe he was 'overloaded'.

The University of Pennsylvania (Penn) invested heavily in the IHGT, which has some 250 employees and an annual budget of \$25 million. Judith Rodin, the university's president, says this investment was not enough. But rather than build up the institute further with its own funds, Penn will look outside for help.

The university is to hire a contract research organization to handle the overseeing of all clinical trials - not only those involving gene therapy - that its Office of Regulatory Affairs considers risky or complicated, and which are not sponsored by pharmaceutical companies.

At the same time, the IHGT will be made smaller, both in terms of budget and staff, although Rodin declines to provide solid numbers. The institute's director, James Wilson, will stay on, but will not be allowed to participate in any clinical trials.

Rodin and the report's lead author, William Danforth, chancellor emeritus of
Washington University in St Louis, are saying publicly what many gene-therapy researchers have said privately since Gelsinger's death that Wilson extended himself too far. Besides his role as institute director, Wilson was involved in several clinical trials, as well as in basic research. "We think Dr Wilson was overloaded," says Rodin.

Penn's relationship with the biotech company that produced vectors for the institute is also uncertain. Genovo, Inc., based in Sharon Hill, Pennsylvania, was founded by Wilson, who has financial interests in it. Its contract with the university ends in June. Rodin declined to say whether it would be renewed.

While Wilson's holdings in Genovo suggested a potential conflict of interest, Danforth says his committee found no evidence of wrongdoing. However, the committee's report states that the public's perception of conflict of interest can be nearly as dangerous as the real thing.

The university may apply to the FDA to run the IHGT's gene-therapy trials through other university programmes. The report questions whether the university should dedicate an entire institute to gene therapy.

"Devoting an institute to human gene therapy suggested a little more confidence that gene therapy could work than might have been justified at the time," says Danforth.

He agrees with the FDA's earlier assessment that Penn made mistakes during the trial, including the monitoring and reporting of adverse effects, but wasn't sure of their impact. "Did those things criticized by the FDA lead to the death of Jesse Gelsinger? I think there is no evidence of that," he says.

\section{... as Harvard keeps its ethics guidelines}

\section{Steve Nadis, Boston}

The Dean of Harvard Medical School (HMS), Joseph Martin, announced last week that the school will not relax its conflictof-interest guidelines, as had been recommended by a senior faculty committee in a report last autumn (see Nature 403, 818; 2000).

The policy, said Martin, would stay as it is except for new safeguards imposed to protect students and other trainees from "potential conflicts created by their mentor's financial interests".

Dennis Kasper, a member of the faculty committee and the executive dean for academic programmes at HMS, notes that the committee's decision was based on "an evolving faculty point of view and was not influenced by outside forces", such as recent critical editorials in medical journals.

But he did say that Martin's participation on a panel that investigated the recent death of a patient in gene-therapy trials at the University of Pennsylvania (see main story) "supported the direction he'd been leaning in all along".

Some medical school researchers are critical of the decision. Cell biologist and haematologist Thomas Stossel, for example, argues that the current policies inhibit the development of valuable drugs. "When researchers discover things that might lead to useful products, I think they are ethically obliged to steer it to the public by going through industry," he says.

Both Martin and Kasper leave open the possibility that Harvard's restrictive guidelines could be changed in the future to bring them more in line with those of other institutions. But they stress that this should only occur after a national forum is held by the leading research universities, government, and industry in the hope of establishing national standards. "All of us should stand by the same ethical rules," says Kasper. 